\title{
Koteksti ja viron ymmärtäminen lähisukukielen pohjalta
}

\author{
PIRKKO MUIKKU-WERNER \\ Itä-Suomen yliopisto
}

Tiivistelmä. Lähisukukielensä ymmärtämiseen pyrkivän tiedetään nojautuvan ensisijaisesti samankaltaisuuteen. Kielten samankaltaisuus ei välttämättä takaa onnistumista, mutta sitä ei aina myöskään ehdottomasti edellytetä. On siksi tutkittava muitakin muuttujia kuin sitä, missä määrin kielet muistuttavat toisiaan: miten esimerkiksi valintojen tilanteinen vapausaste ohjaa kääntämistä?

Kiinnostava kysymys on se, miten sukukielistä tekstiä kääntävän viroa osaamattoman suomalaisen ratkaisuihin vaikuttaa koteksti, lähiteksti. Mitä merkitystä on sillä, jos äidinkielisen ilmauksen kerasanojen määrä on rajallinen ja tämänkaltainen samanlaisuusoletus ulotetaan viroon tai jos vironkielisen sanan vierussanaltaan "vaatima" sijamuoto eroaa suomenkielisestä rektiosta?

Analysoimieni esimerkkien perusteella vaikuttaa siltä, että tarjoutuvien kollokaattien niukkuus johtaa oikean vastineen löytymiseen vieläpä silloinkin, kun käytetty virolainen ilmaus ei muistuta suomalaista. Sitä vastoin vierussanan odotuksenvastainen muoto voi tuottaa tunnistamisvaikeuksia. Viron sijavalinnan erilaisuus vaikeuttaa jopa samankaltaisten sanojen kääntämistä.

Miten sitten voitaisiin hyödyntää erilaisten fraseologisten yksiköiden kiinteyttä edistettäessä reseptiivistä monikielisyyttä? Esimerkiksi äidin ja isän yhteisesiintymisen todennäköisyys (semanttinen priming) on universaalia. Semantiikan käyttökelpoisuus sukukielen ymmärtämisen tehostamisessa vaatii lisätutkimusta.

Avainsanat: reseptiivinen monikielisyys; samankaltaisuus; fraseologinen yksikkö; kollokaatio; rektio; semanttinen pohjustus 


\section{Lähisukukielisen tekstin ymmärtämisen edellytyksiä}

Useissa tutkimuksissa on jo osoitettu, että lähisukukielen ymmärtäminen äidinkielen pohjalta ilman muodollista opetusta on mahdollista. Eniten hyötyä on samankaltaisuudesta, joka mahdollistaa kielten elementtien, kuten sanaston ja muotojen, sekä erilaisten prosessien, kuten taivuttamisen, siirtymisen. Reseptiivinen monikielisyys (ks. tarkemmin esim. Zeevaert \& ten Thije 2007) on tavanomaisinta suullisessa vuorovaikutuksessa, jossa siihen osallistuvat puhuvat kukin äidinkieltään. Merkitys on toki mahdollista tavoittaa myös teksteistä, mikäli ne eivät ole liian monimutkaisia ja niiden aihepiiri on lukijalle tuttu. On havaittu, että vastaavuudet on helpompi havaita kirjoitetusta kuin puhutusta kielestä. Tämä voi osaksi johtua siitä, että lukijalla on enemmän aikaa käytettävissään ja hän pystyy palaamaan tekstiin toistuvasti (Berthele 2008: 92; Vanhove 2014: 99).

Samankaltaisuus ei kuitenkaan takaa ymmärtämistä vaikkapa yritettäessä tavoittaa vironkielisten sanojen merkitystä suomen kieleen nojautuen ("petollisista ystävistä” ks. esim. Laalo 1992), eikä se ole merkityksen tavoittamisen ainoa edistäjä. Myös muun muassa koherentin tekstikokonaisuuden tuki, maailmantieto ja metalingvistinen tietoisuus helpottavat viestin tajuamista. Lisäksi suomen eri maantieteellisten, stilististen ja ajallisten varieteettien hallinta on eduksi, koska esimerkiksi joidenkin viron sanojen samankaltainen suomalainen vastine on nykysuomen yleiskielessä harvinainen. Informanttien osaamat vieraat kielet puolestaan auttavat kansainvälisen sanaston tunnistamista. (Ks. esim. Muikku-Werner 2013: 222, 229-230.)

Kiistatta on kuitenkin todistettu, että samankaltaisuus useimmiten edistää sukukielten keskinäistä ymmärtämistä. Erityisen selvä positiivinen vaikutus on toisiaan muistuttavilla sanoilla. Silti irralliselle, äänteellisesti jopa vain niukasti lähtökielisestä poikkeavalle kohdekieliselle sanalle tarjotaan käännösvastineita hyvin runsaasti. Jos taas sama sana on sijoitettu lauseyhteyteen, osaksi tekstiä, vastineiden määrä on huomattavasti niukempi. Ympäröivän tekstin merkitystä ei siis sovi 
vähätellä: mieleen tulevista vaihtoehdoista valitaan se, joka rakentaa järjellisen kokonaisuuden muiden lekseemien kanssa. (Muikku-Werner \& Heinonen 2012; Paajanen 2012; Muikku-Werner 2013.) Siksi reseptiivisen monikielisyyden edellytysten tarkastelu on syytä ulottaa yksittäisten sanojen tai rakenteiden tasolta pidempiin fraseologisiin yksiköihin.

Mitä sitten pitäisi ottaa huomioon, jos käännämme katseemme tekstiin? Meillä on käytettävissämme kielisysteemi, äidinkielen merkityspotentiaali, jolla tarkoitetaan kielellisten valinnanmahdollisuuksien järjestäytynyttä joukkoa. Hallidayn systeemis-funktionaalisessa teoriassa metafunktioiden kautta voidaan kuvata, miten kielen systeemi on jäsentynyt erityyppisten merkitysten ilmaisutehtäviä ja toimintoja varten. Kulloinkin käsiteltävän aiheen kannalta on keskeistä, että kieli tarjoaa resurssit tekstien rakentamiseen. Kielellä onkin muun muassa tekstuaalinen metafunktio, eli se luo koherenttia tekstiä eikä vain satunnaisia virkejonoja ja suhteuttaa viestimme ympäröivään tekstiin. Toisaalta tekstien koherenttius asettaa etenemiselle tiettyjä vaatimuksia. Koossa pysyvälle tekstille on ominaista muun muassa tematiikka eli ne mekanismit, jotka säätelevät virkkeen sisältämän informaation linearisointia eli semanttisen pintainformaation virtaamista. Merkkien välisistä suhteista koostuva systeemi auttaa merkitysten ymmärtämistä. (Halliday 1973: 42-44; 1978: 39-41, 192; Thompson 1996: 28.)

Suuri merkitys sukukielen ymmärtämisprosessissa on lingvistisellä tiedolla (Hufeisen \& Marx 2007: 308; Singer 2007: 343). Se yhdistetään usein nimenomaan sanastoon ja muotoihin, mutta se kytkeytyy tekstuaaliseen metafunktioonkin. Teksti tai tekstisekvenssi toimii tietyssä ko(n)tekstissa, jossa lingvistiset yksiköt voivat valikoitua ja kombinoitua eri tavoin mutta jossa myös tekstin tuottaja ja lukija arvioivat ilmausten onnistuneisuutta kussakin tilanteessa. Äidinkielistä tekstiä lukeva ei yleensä kiinnitä huomiota siihen, täyttävätkö tekstin ilmaukset johdonmukaisuuden vaatimuksen. Vasta kun ainesten yhteensopimattomuus kasvaa riittävästi, lukija havahtuu huomaamaan tekstin jotenkin poikkeukselliseksi. On todennäköistä, että erilaiset odotukset kohdistuvat 
muunkielisiinkin teksteihin ja temaattisen yhtenäisyyden voi olettaa vaikuttavan asiasisällön hahmottamiseen.

Luotaessa kirjoitetusta tekstistä järjellistä kokonaisuutta tarvitaan päättelyä ja tietyntyyppistä karsintaa. Vaikka sanaston samankaltaisuus on tietysti ymmärtämisen tärkeä edellytys, oikeaan merkitykseen on mahdollista päätyä silloinkin, kun sanaa ei enää voi tunnistaa ulkoasun perusteella sukulaissanaksi tai sukulaisuutta ei ole. Tällöin outo sana saatetaan prosessoida kotekstin perusteella. Toisen - esimerkiksi samankaltaisuuden perusteella tunnistetun - sanan uskotaan edellyttävän jonkin toisen sanan myötäesiintymistä, ja sanaa käyttäessämme otamme ehkä tiedostamattamme huomioon muun muassa sen tyypilliset kerasanat. Tällaista kahden lähekkäin olevan sanan (jopa tilastollisesti merkitsevää) yhteisesiintymää nimitetään kollokaatioksi. (Firth [1968]1957: 179; Sinclair 1996: 81; Jantunen 2009: 356.) Se tyypillinen oletus, että tutuksi todetun virolaisen sanan kollokaatit ovat samoja kuin sen suomalaisella vastineella eli sitä käytetään samantapaisesti, voi osua oikeaan.

Gass ja Selinker (1994: 288) ovat todenneet, että leksikaalisia taitoja punnittaessa sanaan liittyvien valintarajoitusten hallinta on hyvin vaikeasti opittava ja opetettava taso. Oppimistulokset paranevat, kun oppijoille selvitetään kollokaatioissa esiintyviä kieltenvälisiä eroja. Millainen on tilanne yritettäessä ymmärtää sukukieltä ilman muodollista opetusta? Onko hyödyksi vai haitaksi, jos samankaltaisuusoletus ulottuu myös vierussanojen laatuun?

\section{Tutkimusaineisto ja tutkimuksen tavoitteet}

Tämä kotekstin vaikutusta ymmärtämiseen pohtiva kirjoitus on osa laajempaa REMU-tutkimusta, ${ }^{1}$ jota on esitelty jo aiemminkin Lähivõrdlusi. Lähivertailuja -julkaisuissa (Kaivapalu \& Muikku-Werner 2010; Paajanen \& Muikku-Werner 2012; Muikku-Werner \& Heinonen 2012; Muikku-Werner 2013). Erilaisten käännöstestien avulla on muun muassa

1 Reseptiivinen monikielisyys: läheisten sukukielten keskinäinen ymmärrettävyys (REMU) -verkosto (ks. http://www.uef.fi/en/remu2015). 
selvitetty, millaisten lekseemien merkitys suomalaisten tai virolaisten on sukukielestään helppo tavoittaa ja millä perusteella. Tällä kertaa tarkasteltavina ovat käännökset Terttu Nurron alun perin englanninkielisestä tekstistä Sild üle mere (ks. liite 1), joka käsittelee virolais-suomalaisia kulttuurisuhteita. Kääntäjinä on 33 joensuulaista ja 18 jyväskyläläistä suomenopiskelijaa, jotka eivät ole opiskelleet viroa. Aineistolla on heikkoutensa, koska kaikki esimerkit sisältyvät teemaltaan yhtenäiseen artikkeliin enkä siksi pysty sanomaan, mikä on tekstikokonaisuuden ja maailmantiedon osuus tehtyihin käännösratkaisuihin. Lisäksi osa vastaajista tyytyy vain selittämään tekstin sisältöä, mistä johtuu "ei käännetty" -vastausten suuri määrä.

Olen jo aiemminkin (Muikku-Werner 2013) lyhyesti sivunnut kotekstin ja ymmärtämisen välistä suhdetta, mutta asiaan on syytä paneutua seikkaperäisemmin. Valitettavasti aineisto ei tarjoa kovin runsasta esimerkistöä aiheesta, koska testit ovat olleet luonteeltaan pilotteja. Niitä ei ole suunniteltu tietyn yksityiskohdan selvittämiseen vaan yleiskuvan luomiseen. Vasta niiden tekeminen on avannut näköaloja kohteisiin, joiden selvittäminen vaatii uusia, entistä tarkempia lähestymistapoja. Kiinnostava kysymys on se, onko mahdollista, että esimerkiksi suomenpuhuja siirtää äidinkielensä vierussanaodotuksen myös viroon. Toisaalta tekstielementteihin kytkeytyvien rakenteellisten olettamusten täyttymättömyys - esimerkiksi se, että rektio ei toteudu lähtökielen mukaisesti - voi haitata merkityksen tavoittamista, vaikka sukukielten sanat muistuttaisivatkin toisiaan.

Pyrin löytämään vastauksia seuraaviin kysymyksiin:

- Miten kirjoitetussa tekstissä koteksti vaikuttaa viron ymmärtämiseen?

- Onko sanan myötäesiintymispreferenssillä vaikutusta merkityksen tavoittamiseen?

- Edistääkö tarjoutuvien kollokaattien niukkuus merkityksen välittymistä niissäkin tapauksissa, kun kohde- ja lähtökielen leksikaaliset elementit eivät muistuta toisiaan? 
- Jos lähtö- ja kohdekielen rektio tai muut sijavalintaratkaisut poikkeavat toisistaan, vaikeutuuko sisällön hahmottaminen?

- Onko olemassa muitakin leksikaalisten yksiköiden muodostamia merkityskokonaisuuksia, joita voisi hyödyntää merkityksen tavoittamiseksi?

Seuraavissa kahdessa analyysiluvussa yritän syventää aiempia huomioitani tulkitsemalla valitsemiani esimerkkejä tarkemmin. ${ }^{2}$ Koska nimenomaan kotekstin merkityksen arviointi vaatii runsaasti lisämateriaalia, pohdin viidennessä luvussa sitä, millaisella tutkimusasetelmalla vaikutusta voisi yrittää jäljittää. Millaisella menetelmällä olisi mahdollista sulkea pois muiden muuttujien, kuten tekstin vaikeusasteen tai informanttien eritasoisen maailmantiedon, vaikutus? Mikäli tällainen metodi olisi kehitettävissä, edellytykset nimenomaan fraseologisten yksiöiden "vakioisten" ainesten ymmärtämiseen saatettaisiin löytää, ja niistä tehdyt havainnot ja mahdolliset säännönmukaisuudet voitaisiin siirtää sukukieltä äidinkielensä pohjalta lukevan - tai kuuntelevan - avuksi.

\section{L1:n kollokaattiodotukset ja L2:n ymmärtäminen}

Virkkeet eivät rakennu sana sanalta, vaan niissä on yleensä useita lausekkeita. Lauseke on rakenne, jonka sana muodostaa mahdollisten laajennustensa kanssa (ISK $₫ 439$ ). Monesti tällaiset monisanaiset yksiköt (esimerkiksi idiomit) saattavat olla hyvinkin jähmeitä, mutta jonkin verran morfologista ja leksikaalista variaatiota niihin sisältyy. Jotkin sanojen kotekstiin suuntautuvat valintarajoitukset ovat hyvinkin tiukkoja; joskus niiden välinen suhde ilmenee melko väljänä valintapreferenssinä. Lekseemit eivät kuitenkaan suhteessa toisiinsa voi esiintyä täysin mielivaltaisessa järjestyksessä, vaan niiden käyttöä ohjaavat lukuisat idiomaattiset esiintymisrajoitukset ja -preferenssit. Syntyperäisellä kielenpuhujalla onkin käytettävänään runsaasti valmiita rakenteita. (Jantunen 2009: 358; käsitteistä idiom principle ja open choice principle mm.

\footnotetext{
2 Osaa esimerkeistä olen käsitellyt lyhyesti jo aiemmin (Muikku-Werner 2013).
} 
Sinclair 1991: 109-115.) Seuraavien kolmen esimerkin avulla esittelen, miten suomenpuhuja käsittelee ja ymmärtää viron kiinteähköjä lausekkeita.

Seuraavan esimerkin aastal ei ole sukulaissana, eikä sen tunnistaminen irrallisena ole todennäköistä.

(1) Instituut asutati aastal 1993.

'Instituutti perustettiin vuonna 1993'.

Äidinkielensä pohjalta informanteilla on kuitenkin selvä käsitys siitä, mikä sana on mahdollinen vuosiluvun ja sen vierussanan muodostamassa yksikössä.

Instituutti avattiin vuonna 1993.

Instituutti aloitti vuonna 1993.

Instituutti perustettiin 1993.

Kelvollisia käännöksiä on kahdenlaisia. Mikäli arvataan tai päätellään oikein sinänsä "petollisen" verbin asutada merkitys 'perustaa' tai viitataan muihin aloittamista implikoiviin toimiin, vuonna (15 kpl) on asianmukainen käännös. Kolmessa tapauksessa esiintyy pelkästään vuosiluku, mikä on luontevaa: onhan vuosiluvuksi tunnistettavan numeraalin yhteydessä vuonna-adverbi tavallaan redundantti. Kysymykseen, onko adverbi jätetty pois vain tarpeettomuuttaan vai aastal-sanan kääntämisen välttämiseksi, on mahdotonta vastata, koska informanteilta ei vaadittu ratkaisujen perustelua. Heistä 29 ei käännä kyseistä kohtaa lainkaan, mihin osasyynä voi olla se, että kyseinen lause sijaitsee loppupuolella tekstiä, joten osa ei ole ehtinyt sitä ehkä kääntää.

Vaikka perustaminen ei tule kaikkien mieleen tekemisen tarkkana laatuna, vastaajat kuitenkin hahmottavat menneeseen aikaan viittaavan vuosiluvun merkitsevän toiminnan alkamista. Olemassaoloon ja aktiviteetteihin liittyy jatkuvuus, joten vuodesta (1993) (4 kpl) on looginen vaihtoehto tarkentaa tapahtumien alkuhetki:

Instituutti on ollut olemassa vuodesta 1993.

Se [Suomen Instituutti] on toiminut vuodesta 1993. 
Kellerman (1983: 117) on todennut, että kielenkäyttäjät ovat vähemmän alttiita siirtämään kohdekieleen tunnusmerkkisiä, kuten harvoin esiintyviä, struktuureja. Esimerkissä 1 vierussana onkin ennakoitavissa nimenomaan fraseologisen yksikön suurtaajuisuuden ja odotuksenmukaisuuden vuoksi; valinnanvapautta ei juuri ole. On havaittu, että myös muodollista opetusta saaneet toisen kielen oppijat hallitsevat parhaiten ne kollokaatiot, joissa ei esiinny monia rinnakkaisia leksikaalisia vaihtoehtoja. Ne omaksuttaneen idiomien tapaan kokonaisina sanastoyksiköinä, mikä on todennäköinen syy muistamisen helppouteen. (Nesselhauf 2003: 233; 2005: 203-204). Sukukieltä ymmärtävä puolestaan pystyy turvautumaan myös äidinkielellä varastoituun fraasiin.

Seuraavan esimerkin sana vaheline on äänteellisesti kaukana suomenkielisestä merkitysvastineestaan välinen. Vaheline saattaa toki assosioitua etymologiseen vastineeseensa vaihe: vaiheilla. Esimerkiksi fraasit kahden vaiheilla ja kahden vaihtoehdon välissä osoittavat, etteivät va(i)he ja väli välttämättä olekaan kovin kaukana toisistaan, mikä on kontekstin lisäksi voinut helpottaa ymmärtämistä. (Remes 2014.)

(2) Soome Instituut asutati --- Soome ja Eesti vaheliste sidemete tugevdamiseks.

'Suomi-instituutti perustettiin --- Suomen ja Viron välisten suhteiden vahvistamiseksi.'

Kyseisen lauseen ymmärtäminen osoittautuu helpoksi. Käännösten verbit eroavat merkitykseltään jonkin verran, mutta kaikista vaihtoehdoista välittyy yhteistyön merkityksen korostaminen. Informanteista 32 kääntää fraseologisen yksikön suunnilleen oikein; substantiivin käännösvastineiden laatu ei ollut tässä yhteydessä kovin relevanttia.

--- Suomen ja Viron välisen siteen turvaamiseksi ---

--- ja Suomen \& Viron välisten suhteiden tiukentamiseksi.

--- ja Suomen ja Viron välisen suhteen vahvistamiseksi.

Osa informanteista (12 kpl) ei käännä jaksoa lainkaan, mikä johtuu siitä, että he selvittävät tekstin sisältöä väljästi referoiden. Informanteista 3 jättää tarpeettomaksi kokemansa vahelise-sanan kääntämättä. Poistaminen 
on näppärä keino prosessoida tekstiä, mutta tutkija ei voi valitettavasti olla varma, onko kääntäjä tarkoituksella luopunut turhasta informaatiosta vai pelkästään väistellyt käännösongelmaa. Tulos kertoo silti tekstin ymmärtämisestä:

--- Suomen ja Viron suhteiden turvaamiseksi ---

--- Suomen ja Eestin siteiden tukemiseksi ---

Yksi kääntäjistä pyrkii luontevaan suomenkieliseen muotoiluun, ja tulos on asiasisällöltään korrekti:

Soome Instituut perustettiin --- vahvistamaan maiden välisiä siteitä.

Edellä olevat käännökset osoittavat hyvin, miten kollokaattien rajallinen määrä kyseisessä yksikössä edistää tekstin ymmärtämistä. Toki muukin ympäröivä teksti myötävaikuttaa onnistumiseen.

Seuraavan esimerkin uus nimi -lausekkeen yhteyteen on ylipäänsä vaikea kuvitella muita predikaattiverbejä kuin antaa tai saada.

(3) Sellele [Suomen Kulttuurikeskus] anti uus nimi.

'Sille [Suomen Kulttuurikeskukselle] annettiin uusi nimi.'

On oletettavaa, ettei suomen annettiin-muotoa lyhyempi anti välttämättä johda kääntäjiä harhaan. Siten tässä myös sanastollisella samankaltaisuudella on todennäköisesti onnistumista tukeva vaikutus.

--- sille annettiin uusi nimi.

--- ja organisaatiolle annettiin uusi nimi.

Käännöksistä 26 onkin oikein. Informanteista 22 ei tekstiä kääntänyt, mihin voi olla syynä ajanpuute. Tämäkin jakso sijoittuu kokonaistekstin loppupuolelle. Toisaalta viron verbinmuodon täydellinen samannäköisyys suomen substantiivin anti kanssa on voinut hämätä jotakuta vastaajaa.

Nimi muutettiin myöhemmin ---

Siksi nimi vaihdettiin.

--- sai myöhemmin nimekseen Suomi-instituutti 
Edellä olevista esimerkeistä kahdessa ensimmäisessä uuden nimen antaminen kiteytetään muuttamiseksi ja vaihtamiseksi, mikä ei muuta asiasisältöä. Viimeisessä esimerkissä on kiinnostava vaihdos: aktiiviset tosin tuntemattomat - toimijat häivytetään, ja toiminnan kohteeksi tulee Instituutti. Syytä vaihdokseen on vaikea arvioida; ehkä anti-muotoa ei ole tunnistettu verbin passiivi- tai impersonaalimuodoksi.Toisaalta merkitys vivahde-erosta huolimatta on sama.

Seuraavissa esimerkeissä on periaatteessa kyse suunnilleen samasta asiasisällöstä kuin edellisissä: Suomen Kulttuurikeskus muuttuu Suomi Instituutiksi.

--- avattiin Suomen Kulttuurikeskus, joka muuttui myöhemmin Suomen Instituutiksi.

--- myöhemmin muuttuen Suomi Instituutiksi.

Muuttumiseen voi kuitenkin ajatella sisältyvän myös muuta kuin pelkkä nimen vaihtaminen; sanan kulttuuri pois jääminen jälkimmäisestä esimerkistä voi implikoida toimintaintressien uudelleen fokusointia. Tosin informantit eivät varmaankaan tätä painopisteen vaihtumista ole miettineet. Kaiken kaikkiaan tämä kollokaattien tasolla vähän valinnan mahdollisuuksia tarjoava lauseke ei tuota käännösongelmia; tosin tässä tapauksessa - toisin kuin esimerkeissä 1 ja 2 - fraseologisen yksikön kaikki jäsenet ovat melko tai hyvin samantapaisia kuin suomessa.

\section{L1:n fraseologisten yksiköiden sijavalinnat ja L2:n ymmärtäminen}

On havaittu, että kohdekielen vaihtoehtojen moninaisuus kumoaa sukukielisyyden myönteisen vaikutuksen: esimerkiksi suomen valinnaisten partitiivimuotojen lukuisuus ja erilaisuus osoittautuvat virolaisille ongelmaksi, vaikkei itse sana olisikaan vieras (Kaivapalu 2005: 82-83, 252-253). Samaan tapaan samankaltaisuuden tuottama apu voi mitätöityä rektioseikkojen vuoksi. Rektio eli sanan täydennysten sijavalinta edustaa omalajistaan kolligaatiota. Kolligaatiossahan on kyse nimenomaan siitä, että sanan ja kieliopillisen kategorian välillä on 
syntagmaattinen suhde eli leksikaalis-kieliopillinen myötäesiintymä. (Firth 1957: 181; Jantunen 2009: 359.)

Edellisen luvun esimerkeissä vaihtoehtojen vähyys edisti ymmärtämistä, mutta kun viron vierussanan muodon määrittävä rektio on erilainen kuin suomessa, ei tuttuakaan fraseologista yksikköä ole välttämättä helppo kääntää. Rektiohan on riippumaton täydennyksen semanttisesta luonteesta, joten täydennykseltä edellytetty sija on mielivaltainen. Rektiosääntöjen oppimiseen ei löydy apua mistään rakenteellisesta järjestelmällisyydestä, vaan ne on vain muistettava. (ISK $\$ 1225$; JönssonKorhola \& White 1997: 5; viron kielen vaikutuksesta suomen rektioiden oppimiseen ks. Nissilä 2011.) Seuraavassa on käsitelty kolmea erilaista tapausta, jossa virolaiset ja suomalaiset sijavalinnat, yhdessä tosin vain “petollisen ystävän” tasolla, poikkeavat toisistaan.

Viron lisaks-sana esiintyy allatiivisijaisen täydennyksen kanssa, kun taas suomessa lisäksi-sanan rektio on genetiivi. Jantunen ja Brunni (2012: 77) ovat kiinnittäneet huomiota morfologiseen pohjustukseen (priming) eli siihen, että fraseologisen yksikön ytimeen kytkeytyy tietyssä muodossa oleva kerailmaus. Tavallisimminhan pohjustus on leksikaalista: sanaa käytetään tyypillisimmin sen kollokaattien kanssa (Hoey 2007: 8). Tässä esimerkissä ongelmia voi odottaa syntyvän siitä, että suomen kielen kannalta odotuksenmukainen genetiivimuotoinen täydennys puuttuu.

(4) Lisaks Soomele ja Eestile on maailmas vaid üks riik, mille riigikeel kuulub soomeugri keelerühma: Ungari.

'Suomen ja Viron lisäksi maailmassa on vain yksi valtio, jonka virallinen kieli kuuluu suomalais-ugrilaiseen kieliryhmään: Unkari'.

Siitä huolimatta että edellisen esimerkin useimmat sanat näyttävät tutuilta, vääriä käännöksiä on 17, oikeita 22; 12 opiskelijaa ei kääntänyt kyseistä yksikköä tai koko virkettä lainkaan. On mahdollista, ettei sana riik ole hahmottunut 'valtioksi', vaikka se esiintyy ruotsinkielisissä nimissä kuten Frankrike ja Österrike. Kuitenkin vastaajien olettaisi siitä huolimatta opintojensa tai yleissivistyksen perusteella hahmottavan jakson sisällön. 
Lisäksi Suomen ja Viron on maailmassa ---

Suomen ja Viron lisäksi maailmassa on vain 1 maa, ---

Ensimmäisessä vastineessa on nähtävissä yksi tyypillinen tapa kääntää: edetään sana sanalta, eikä päädytä luontevaan äidinkieliseen rakenteeseen. Vaikka rektio onkin muutettu oikeaksi, sanajärjestyksen epäodotuksenmukaisuus tuo tekstiin vanhahtavan - jopa runollisen - sävyn, mikä ei sinänsä tietysti haittaa ymmärrettävyyttä. Jälkimmäiseen oikeaan vaihtoehtoon verrattuna stilistinen ero on kuitenkin selvä.

Seuraavassa käännöksessä on genetiivin asemesta valittu ulkopaikallissija.

Lisäksi suomelle ja virolle on vain yksi ... tämä kieli kuuluu suomenugrilaiseen kieliryhmään: unkari.

Tarjokkaassa on nojauduttu täysin vironkieliseen tekstiin, mikä johtaa suomen kannalta epäidiomaattiseen tulokseen. Toinenkin selitys on mahdollinen: koska rektio on suomalaisittain outo, fraseologinen yksikkö on purettu, ja lisaks-prepositio muuttuu konnektiiviseksi, koko lausetta määrittäväksi irralliseksi adverbiaaliksi (ISK § 963). Toisaalta informantin tapa jatkaa virkettä puuttuvan aineksen (merkitty kolmella pisteellä) jälkeen ei välttämättä tue jälkimmäistä selitystä.

Lisäksi Suomella ja eestillä on maailmassa vielä yksi kieli, ---

Lisäksi suomella ja virolla on olemassa yhteinen sukulainen, ---

Prepositiomerkityksen väistyminen on todennäköisesti oikea tulkinta edellisistä adessiivimuotoon tukeutuvista käännöksistä. Tuloksena on lausetta määrittävä adverbiaali ja omistusrakenne, joka on outo ensimmäisessä esimerkissä mutta mahdollinen kääntäjän rakentamassa toisen esimerkin kontekstissa. Sen sijaan alkuperäiseen tekstiin possessiivisuus ei sovi: ${ }^{\star S u o m e l l a ~ j a ~ V i r o l l a ~ o n ~ y k s i ~ v a l t i o, ~ j o n k a ~ k i e l i ~---~ . ~}$

Suomalais-ugrilaiseen kieliryhmään kuuluu lisäksi unkarin kieli. Lisäksi maailmassa on vain yksi kieli, --- 
Kun tietyt yksittäiset ainekset, kuten riik, ovat ilmeisesti tuottaneet kääntäjille ongelmia, he pelkistävät asian. Ratkaisut kertovat kuitenkin tekstin sisällön ymmärtämisestä: todetut seikathan ovat tuttuja.

Esimerkin 5 muoto logol liittyy paikallissijajärjestelmien käyttöeroihin. Virossa jollain pinnalla (laajasti ymmärtäen) olevaa ilmaistaan ulkopaikallissijoilla, kun suomessa on vastaavissa tapauksissa sisäsija: esimerkiksi pildil / fotol on mu vend 'kuvassa on veljeni', uksel on silt 'ovessa on kyltti' tai ümbrikul on postmark 'kirjekuoressa on postimerkki'. (Pajusalu ym. 1999: 107.)

(5) --- kaarsilda on kasutadud ka instituudi logol ---

' --- kaarisiltaa on käytetty myös instituutin logossa --- '

Kääntämisen ongelmallisuus (10 väärin, 23 ei käännöstä) johtunee osittain siitä, että verbi kasutada on vieras, ei niinkään siitä, ettei fraseologista yksikköä instituudi logol tunnistettaisi. Oikeita ratkaisuja toki on $(18 \mathrm{kpl})$. Aina suomen verbi ei täsmällisesti ole viron verbin vastine, mutta keskeinen informaatio saadaan välitetyksi.

Kaarisilta esiintyy instituution logossa.

Muualla kaarisiltaa on käytetty myös instituutin logossa.

Jos informantti ei rohkene irrottautua alkutekstistä, ei tuloksena ole kovinkaan ymmärrettävää tekstiä. Esimerkiksi verbi asettaa liittyy suomessa allatiiviin, ei adessiiviin:

--- ___ on Instituutin logolla, ---

Muiden kaarisilta on asetettu instituutin logolla, ---

Kiinnostava tapa välttää käännösongelma on turvautua ekvatiivilauseeseen. Näin ilmaistuna entiteettien välinen suhde on suoraviivainen.

Instituutin logokin on kaarisilta ---

Kaarisilta on instituutin logo.

Tähän suhteeseen viittaa myös Suomen instituutin logo, kaarisilta, --- 
Viimeisessä esimerkissä on pelkistäminen viety pisimmälle: kaarisillan ja logon samatarkoitteisuuden osoittamisesta on jätetty semanttisesti "tyhjä" olla-verbikin pois.

Siksi kaarisilta on otettu instituutin logoksi, ---

Kaarisilta onkin korostamassa instituution logoa ---

Edellä olevat kaksi esimerkkiä kertovat vapaamman käännöksen suosimisesta. Eri verbien kanssa tarjoutuu muitakin sijoja kuin alkuperäisen tekstin paikallissija välittämään keskeisen tiedon.

Seuraava, viimeinen esimerkki (6) eroaa edellisistä sikäli, että niin suomen jonka-muoto kuin sitä vastaava viron mille-muotokin ovat genetiivejä. Mille on kuitenkin muodoltaan näennäisesti erilainen kuin jonka, koska se muistuttaa suomen allatiivia. Allatiiviksi oletettu muoto saattaa olla syy hämmennykseen.

(6) --- vaid üks riik, mille riigikeel kuulub soomeugri keelerühma: Ungari. '--- vain yksi valtio, jonka virallinen kieli kuuluu suomalais-ugrilaiseen kieliryhmään: Unkari'

Oikeita käännöksiä on 14, ja kääntämättä kyseinen kohta on jäänyt 22 informantilta. Jollain tapaa loogisia käännöksiä on 15.

--- vain 1 maa, jonka virallinen kieli kuuluu suom.ugrilaiseen kieliryhmään: Unkari.

--- vain yksi valtio, jonka valtionkieli kuuluu suomalais-ugrilaiseen kieliryhmään: Unkari.

Huolimatta allatiivimuodosta ne, jotka ovat kyseisen kohdan ylipäänsä kääntäneet, ovat varsin usein päätyneet täysin oikeaan ratkaisuun. Siten allatiivia muistuttava muoto ei ole ainakaan ainoa syy haparointiin.

--- vain yksi serkku, joka kuuluu suomalais-ugrilaiseen kieliryhmään: Unkari.

--- valtionkieli, joka kuuluu suom. ugr. Kieliryhmään: Unkari.

--- vain yksi --- mihin --- kuuluu suomalaisugrilainen kieliryhmä:

Unkari. 
Edellisissä esimerkeissä fraseologinen yksikkö mille riigikeel hajoaa, ja relatiivipronominin joka kohteeksi tulee kieli tai muu aines. Alkuperäistekstin pronominin referenttinä oleva sana riik aiheuttaa viestin etenemisessä ylimääräisen “mutkan”, jonka kääntäjät ovat oikaisseet. Viimeisestä esimerkistä näkyy hyvin yksi kääntämisprosessin laadullinen ominaisuus: erilliset sanat on ymmärretty, mutta viimeisteltyä tekstikokonaisuutta ei ole osattu tai ehditty muodostaa. Ajatus on kuitenkin todennäköisesti mennyt perille.

Mikäli sanaa riik ei ole tunnistettu, on päädytty ratkaisuihin, jossa genetiivirakenne ei ole välttämätön. Tällöin tekstiä käännetään varsin vapaasti:

Suomelle ja virolle pitää seuraa vain Unkari.

Suomen ja Viron lisäksi suomalais-ugrilaiseen kieliryhmään kuuluu unkari.

Suomen ja viron kieli kuuluvat myös samaan kieliryhmään, suomalaisugrilaiseen.Tähän ryhmään kuuluu myös unkarin kieli.

Ensimmäisessä esimerkissä on kehitelty sellainen koteksti, johon virkkeen alkuosan hämmentävä allatiivikin (lisaks Soomele ja Eestile) on saatu luontevasti sijoitettua. Pitää seuraa on asiatyylisessä tekstissä hieman yllättävä, mutta merkitykseltään periaatteessa korrekti. Relatiivilauseesta luopuminen sujuvoittaa tekstiä toisessakin esimerkissä. Sen sijaan viimeisessä esimerkissä kääntäjä joutuu turvautumaan varsin pitkään selostukseen, mikä ei silti estä kokonaisuuden hahmottamista.

Useissa edellisistä esimerkeistä strategiana on poisto. Viestin keskeisen sisällön välittymistä ei typistäminen haittaa. Informanttien mielestä tämä virke oli yksi tekstin helpoimmista, joten vaikka itse asia onkin voitu ilmaista monin eri tavoin, ei ymmärtämisongelmia ilmeisesti ole ollut. 


\section{Pohdintaa}

Edellä olevien muutaman esimerkin avulla olen yrittänyt havainnollistaa, ettei tietyissä tapauksissa samankaltaisuus ole välttämätön edellytys viron ymmärtämiselle ja että samankaltaisetkin sanat voivat jäädä ymmärtämättä nimenomaan kotekstin vaikutuksesta. Edellisessä tapauksessa (luku 3) ymmärtämistä auttaa se, että myötäesiintymispreferenssi rajoittaa tarjolla olevia vaihtoehtoja, jälkimmäisessä (luku 4) äidinkielestä poikkeava rektio tai muu sijanvalinta taas vaikeuttaa ymmärtämistä. Ymmärtämistä helpottavat tekijät eivät aina ole kielisukulaisuuden tuottamaa lisäetua, vaan päättely on "universaalia", ei yksinomaan kielikohtaista: vuosiluvun yhteydessä monissa kielissä on vierussanana vuonna-sanan vastine.

Viime aikoina onkin ollut esillä ajatus siitä, että keskinäinen ymmärrettävyys koskee muitakin kuin läheisiä sukukieliä. Se olisi monikielisen kommunikaation näkökulmasta dynaaminen prosessi, ei kielten luontainen ominaisuus. Tällöin huomio kiinnittyy siihen, miten kuulija passiivisella kielellään tai varieteetillaan havainnoi lingvististä toimintaa, jolloin aktivoituu lingvististen, mentaalisten, interaktiivisten ja kulttuurienvälisten kompetenssien kokonaisuus. (Ns. lingua receptivasta ks. tarkemmin Rehbein ym. 2011: 249, 253-254.) Aiemminkin (ks. esim. Hufeisen \& Marx 2007: 308; Lüdi 2006: 173-174) on todettu, että monikielisyys on vaativa kognitiivinen ja lingvistinen tehtävä, johon on kouluttauduttava.

Olisi selvitettävä, millä tavoin kielikyvyn eri ulottuvuudet merkitystä etsittäessä tukevat kielellistä päättelyä. Yksi mahdollinen keino perustuu sanojen rinnakkaisuuteen: tietyillä sanoilla on tapana nimenomaan merkityksensä vuoksi esiintyä yhdessä eli pohjustaa (prime) toistensa esiintymistä. Kytkentöjen laatua on tutkittu paljon kokeellisesti ja on todettu, että ärsykkeeseen reagoinnin nopeus ja tarkkuus lisääntyvät, mikäli ärsykkeeseen kytkeytyy aiemmin koettuja tapahtumia, kokemuksia, käsitteitä ja ilmauksia. (Ks. esim. Neely 1991; McNamara 2005.) Kielellisten ainesten semanttisen likeisyyden hyötyjä on havainnoitu myös 
sanojen tunnistamisten sekä lauseiden ja keskustelujen ymmärtämisen tutkimuksessa. McNamara (2005: 4) kiinnittää sanaparien yhteisesiintymisten suurtaajuisuuden lisäksi huomiota myös semanttiseen pohjustukseen: reagointinopeutta mittaavissa testeissä koira yhdistetään nopeammin kissaan kuin pöytään. Virittävä sana aktivoi semanttisen kenttään kuuluvat muut ilmaukset (mts. 11 ja 18). Nimenomaan sellaista tekstiä, jossa jokaisessa lauseessa jokin sen jäsen kytkeytyy merkityksen kautta johonkin lauseen toiseen jäseneen, kutsutaan tekstilingvistiikassa sidosteiseksi. Nämä niin kutsutut sidosjäsenet voivat viitata samaan tarkoitteeseen (koira, hauva, rakki, Tessu), tai ne linkittyvät toisiinsa yhteisviitteisyyden kautta: niillä on jokin yhteinen nimittäjä, semanttinen piirre (esimerkiksi talvella ja kesällä "vuodenaikuus"). (Sidosteisuudesta ja viitteisyydestä ks. tarkemmin esim. Enkvist 1975: 32-37, 42-45).

Voidaanko tällaista kokemusperäistä informaatiota hyödyntää sukukielen ymmärtämisessä? Tätä asiaa on alustavasti tarkasteltu isomman kokonaisuuden yhteydessä testattaessa yhden virkkeen kääntämistä. Lauseen Sellel pildil on minu ema ja õde 'Tässä kuvassa ovat äitini ja sisareni' rinnastetut subjektit moni kääntää 'äidiksi' ja 'isäksi'. Tässä tulkinnassa käytetään odotetusti hyväksi yhteisviitteisyyttä: valinnat ovat lähiomaisten nimityksiä. Kuitenkin tässä tapauksessa kääntäjä tarkentaa semanttista kenttää vanhemmuuteen; äidin luontevin semanttinen "täydentäjä" on tietysti isä, joka kollokaattinakin on suurtaajuisempi kuin sisar. Kukaan ei käännä õde-sanaa 'koiraksi'. (Paajanen \& MuikkuWerner 2012: 245.) Yksi esimerkki ei tietysti todista vielä mitään, vaan tarvitaan suuri aineisto todentamaan oletukset semanttis-kohesiivisten kytkentöjen hyödyntämisen myönteisestä vaikutuksesta.

Seuraavaksi onkin tarkoitus testata, minkälaiset tekstijäsenten väliset suhteet mahdollisesti helpottavat sanojen merkitysten päättelyä. Yhteisviitteisiä sidosjäseniähän voivat kytkeä toisiinsa vastakohtaisuus (kevad 'kevät' $\leftrightarrow$ sügis 'syksy'), sisältyvyys (hüatsint 'hyasintti' $\rightarrow$ lill 'kukka'), semanttisen kentän tarjoamat vaihtoehdot (roos 'ruusu' $\leftrightarrow$ tulp 'tulppaani'), syy-seuraus-suhde (rasedus 'raskaus' $\rightarrow$ laps 'lapsi') tai skemaattinen implikaatio (jõulud 'joulu' $\rightarrow$ kingitus 'lahja'). Mikäli 
jompikumpi sidosjäsen on samankaltaisuuden vuoksi läpinäkyvä, toinen on mahdollista päätellä semanttisen pohjustuksen perusteella. Jos lauseessa on puhe hüatsintista, myös yläkäsite lill voidaan lopulta tunnistaa, vaikkei se olisikaan sukulaissana: Vaasis on ilusad lilled, hüatsindid ja roosid 'Maljakossa on kauniita kukkia, hyasintteja ja ruusuja'.

Oikean merkityksen löytyminen perustuu universaaliseen tietoon, johon sisältyy metalingvistisiä käsityksiä tekstin koossa pysymisestä ja viittaussuhteiden luonteesta sekä semanttisten kenttien rakenteesta. Tällainen tieto sivuaa maailmantietoa, kertovathan merkityskentät siitä, miten maailmaa voi hahmottaa vaihtoehtoisin tavoin (Larjavaara 2007: 152). Maailmantietoon sisältyy myös informaatiota tapahtumista ja henkilöistä, mutta nyt käsiteltävinä ovat fokusoidummat kieleen keskittyvät, ennen kaikkea tekstuaaliset ja semanttiset, ratkaisut. Oletus viron ja suomen samankaltaisuudesta koskee toki sanastoa, mutta ei suoran vastaavuuden vaan semanttisen sidoksisuuden tasolla. Jotta samantapainen päättely onnistuisi muiden kuin sukukielten välisenä prosessina, olisi jonkin leksikaalisen elementin oltava tuttu kyetäkseen toimimaan virittäjänä oikeaan semanttiseen kenttään. Jos osaan saksan sanan der Vater, oletan että sen seurassa viihtyy die Mutter. Periaatteessa strategiasta voi olla jossain määrin apua myös vieraan kielen tietoisessa opiskelussa eikä vain pyrittäessä ymmärtämään toista kieltä esimerkiksi äidinkielen pohjalta.

Kääntämistesteistä saatuja tähänastisia tuloksia arvioitaessa on otettava huomioon kaksi seikkaa. Opiskelijoilla oli käytettävissä aikaa varsin niukasti, joten koko tekstin kääntämiseen, saati käännöksen hiomiseen, ei ollut mahdollisuutta. Ohjeistuksessa ei korostettu sitä, että käännöksen olisi hyvä olla luontevaa suomea tai että olisi pyrittävä sanatarkkaan käännökseen. Näin ollen kiireessä on yhtäältä voitu tyytyä muotoiluun, jonka on arveltu välittävän keskeisen sisällön, toisaalta ei ole käännetty helppojakaan kohtia, jos ei ole saatu aikaan kokonaista virkettä. Lisäksi havaintoja ei voi missään tapauksessa yleistää, koska aineisto on pieni.

Jatkossa suunniteltaessa käännöstestiä virosta suomeksi (tai suomesta viroksi) on otettava huomioon ainakin seuraavat tekijät: 
1) Ympäröivän tekstin vaikutuksen eliminointi: tekstin on oltavan riittävän helppoa, ettei tarkkailtavana oleva sekvenssi jää kokonaan kääntämättä.

2) Kääntämisen ohjeistus: informanttia pyydetään kääntämään kaikki yksittäiset sanat mahdollisimman tarkkaan, sillä liian vapaa käännös voi jättää tutkittavan kohteen huomiotta.

3) Osumatarkkuus: yhtäältä on poistettava rinnakkaisten 'oikeiden' käännösten mahdollisuus, etteivät vaihtoehtoiset ratkaisut sekoita tulosta; toisaalta osa tehtävistä voi keskittyä yhteen ilmiöön liittyvien esimerkkien kääntämiseen.

4) Tekstin pituus: mikäli teksti on hyvin pitkä, ajanpuute tai tarkkaavaisuuden herpaantuminen voivat heikentää tulosta.

5) Tekstikäännösten 'samanlaisuus': viron- ja suomenkielisten tekstien yhdenmukaisuuteen on kiinnitettävä erityistä huomiota.

6) Kääntämisen rinnalle on otettava myös muita tiedonhankinnan menetelmiä ( $\mathrm{mm}$. haastattelut, ääneen ajattelu), jotta asianomaisten ratkaisut eivät jää arvailujen varaan, vaan heiltä voidaan tiedustella niiden perusteita.

Kaikkia häiritsevien muuttujien vaikutusta ei varmastikaan pystytä eliminoimaan. Tärkeintä on, että ohjeistus on riittävän yksiselitteinen.

Sanaa laajempien kokonaisuuksien merkitystä miettiessä huomion voi kohdistaa myös sovelluksiin: miten tuloksia voisi käyttää hyväksi tehostettaessa lähisukukielen ymmärtämistä äidinkielen pohjalta? Aiemmin on pohdittu esimerkiksi sitä, missä formaalisen opetuksen vaiheessa fraasirakenteita voidaan opettaa (Jantunen 2009: 373). Sukukielen ymmärtämisessä tilanne on monesti helpompi, kun ympäröivän sanaston tuttuuden perusteella fraseologisen yksikön merkitys voi olla melko vaivattomasti pääteltävissä, varsinkin jos kyseessä on kombinaatio, joka esiintyy neutraalissa rekisterissä taajaan (opetuksen kannalta ks. tarkemmin Nesselhauf 2003: 238). REMU-verkoston tavoitteena on saada syksyn 2014 aikana kehitettyä sukukielten ymmärtämistä mittaavat lopulliset testit. Entistä luotettavampien tulosten toivotaan siirtyvän vähitellen myös käytännön ohjeistuksiin. Uudeksi haasteeksi jää sen 
osoittaminen, onko ymmärtämisessä apua siitä, että yhtäältä tarkastellaan myös pidempiä fraseologisia yksiköitä, toisaalta hyödynnetään tekstin kohesiivisuutta rakentavien sidosjäsenten luomaa semanttista pohjustusta vierussanojen merkitysten päättelyssä.

\section{Kiitokset}

Kiitän nimettömiä arvioijia kiinnostavista ja tarpeellisista kommenteista. Erityiskiitoksen ansaitsee kollegani Hannu Remes, joka vaivojaan säästämättä on vastannut lukuisiin kysymyksiini ja korjannut kömmähdyksiäni.

\section{Lähteet}

Berthele, Raphael 2008. Dialekt-Standard Situationen als embryonale Mehrsprachigkeit. Erkenntnisse zum interlingualen Potenzial des Provinzlerdaseins. - Sociolinguistica 22, 87-107.

Enkvist, Nils Erik 1975. Tekstilingvistiikan peruskäsitteitä. Helsinki: Gaudeamus.

Firth, John Rupert 1957. Papers in Linguistics 1934-51. Oxford: Oxford University Press.

Firth, John Rupert [1968] 1957. A synopsis of linguistic theory, 1930-55. - Frank Robert Palmer (Ed.). Selected Papers of J. R. Firth 1952-59. London: Longman, 168-205.

Gass, Susan M., Larry Selinker 1994. Second Language Acquisition. Hillsdale: Lawrence Erlbaum.

Halliday, Michael A. K. 1973. Explorations in the Functions of Language. London: Edward Arnold.

Halliday, Michael A. K. 1978. Language as a Social Semiotic. London: Edward Arnold.

Hoey, Michael 2007. Lexical priming and literary creativity. - Michael Hoey, Michaela Mahlberg, Michael Stubbs, Wolfgang Teubert (Eds.). Text, Discourse and Corpora. Theory and Analysis. London: Continuum, 7-29.

Hufeisen, Britta, Nicole Marx 2007. How can DaFnE and EuroComGerm contribute to the concept of receptive multilingualism. - Jan D. ten Thije, Ludger Zeevaert (Eds.). Receptive Multilingualism. Linguistic Analyses, Language Policies and Dialectic Concepts. Amsterdam: John Benjamins, 307-321. 
ISK = Auli Hakulinen, Maria Vilkuna, Riitta Korhonen, Vesa Koivisto, Tarja Riitta Heinonen, Irja Alho 2004. Iso suomen kielioppi. SKS:n toimituksia 950. Helsinki: Suomalaisen Kirjallisuuden Seura.

Jantunen, Jarmo 2009. "Minulla on aivan paljon rahaa" - Fraseologiset yksiköt suomenkielen opetuksessa. - Virittäjä 113 (3), 356-381.

Jantunen, Jarmo, Sisko Brunni 2012. Morfologinen priming ja fraseologia vieraan kielen oppimisessa: korpustutkimus oppijansuomesta. - Lähivõrdlusi. Lähivertailuja 22, 71-100. http://dx.doi.org/10.5128/LV22.03

Jönsson-Korhola, Hannele, Leila White 1997. Tarkista tästä: suomen sanojen rektioita suomea vieraana kielenä opiskeleville. Helsinki: Finn Lectura.

Kaivapalu, Annekatrin 2005. Lähdekieli kielenoppimisen apuna. Jyväskylä Studies in Humanities 44. Jyväskylä: Jyväskylän yliopisto.

Kaivapalu, Annekatrin, Pirkko Muikku-Werner 2010. Reseptiivinen monikielisyys: miten suomenkielinen oppija ymmärtää viroa äidinkielensä pohjalta? - Lähivõrdlusi. Lähivertailuja 20, 68-97. http://dx.doi.org/10.5128/ $\underline{\text { LV20.03 }}$

Kellerman, Eric 1983. Now you see it, now you don't. - Susan Gass, Larry Selinker (Eds.). Language Transfer in Language Learning. Rowley, MA: Newbury House, 112-134.

Laalo, Klaus 1992. Huvitav lugu - kiinnostava juttu. Suomen ja viron välinen sanaston riskiryhmä ja sen tausta. Suomi 164. Helsinki: Suomalaisen Kirjallisuuden Seura.

Larjavaara, Matti 2007. Pragmasemantiikka. SKS:n toimituksia 1077. Helsinki: Suomalaisen Kirjallisuuden Seura.

Lüdi, Georges 2006. Multilingual repertoires and the consequences for linguistic theory. - Kristin Bührig, Jan D. ten Thije (Eds.). Beyond Misunderstanding. Linguistic Analyses of Intercultural Communication. Amsterdam: John Benjamins, 11-42.

McNamara, Timothy P. 2005. Semantic Priming. Perspectives from Memory and Word Recognition. New York: Psychology Press. http://dx.doi. org/10.4324/9780203338001

Muikku-Werner, Pirkko 2013. Vironkielisen tekstin ymmärtäminen suomen kielen pohjalta. - Lähivõrdlusi. Lähivertailuja 23, 210-237. http://dx.doi. org/10.5128/LV23.09

Muikku-Werner, Pirkko, Maria Heinonen 2012. Lumesadu - 'tarina' vai 'lumikasa' vai ei kumpikaan? Suomalaiset lukiolaiset viron sanoja tunnistamassa. Lähivõrdlusi. Lähivertailuja 22, 157-187. http://dx.doi.org/10.5128/ $\underline{\text { LV22.06 }}$ 
Neely, James H. 1991. Semantic priming effects in visual word recognition: A selective review of current findings and theories. - Derek Besner, Glyn W. Humphreys (Eds.). Basic Progresses in Reading and Visual Word Recognition. Hillsdale, NJ: Erlbaum, 264-333.

Nesselhauf, Nadja 2003. The use of collocations by advanced learners of English and some implications for teaching. - Applied Linguistics 24 (2), 223-242. http://dx.doi.org/10.1093/applin/24.2.223

Nesselhauf, Nadja 2005. Collocations in a Learner Corpus. Amsterdam: Benjamins. http://dx.doi.org/10.1075/scl.14

Nissilä, Leena 2011. Viron kielen vaikutus suomen kielen verbien ja niiden rektioiden oppimiseen. Acta Universitatis Ouluensis B 99. Oulu: Oulun yliopisto.

Paajanen, Ilona 2012. Kitsas tee - 'laiha tee' vai 'kapea tie? Suomen kielen opiskelijat ja viron ymmärtäminen testissä. Pro gradu -tutkielma. Itä-Suomen yliopisto.

Paajanen, Ilona, Pirkko Muikku-Werner 2012. Tee on kitsas - onko 'tee kitkerää' vai oletteko 'te saita'? Suomalaiset opiskelijat viroa ymmärtämässä. - Lähivõrdlusi. Lähivertailuja 22, 219-258. http://dx.doi.org/10.5128/LV22.08

Pajusalu, Renate, Merja Hietaharju, Viive Taro, Kai Yallop 1999. Keelesild. Viron kielen oppikirja. Helsinki: Otava.

Rehbein, Jochen, Jan D. ten Thije, Anna Verschik 2011. Lingua receptiva (LaRa) - remarks on the quintessence of receptive multilingualism. International Journal of Bilingualism 16 (3), 248-264. http://dx.doi. org/10.1177/1367006911426466

Remes, Hannu 2014. Sähköpostiviesti 28.3.2014.

Sinclair, John 1991. Corpus, Concordance, Collocation. Oxford: Oxford University Press.

Sinclair, John 1996. The search for units of meaning. - Textus IX, 75-106.

Singer, Murray 2007. Inference processing in discourse comprehension. M. Gareth Gaskell (Ed.). The Oxford Handbook of Psycholinguistics. Oxford: University Press, 343-359.

Thompson, Geoff 1996. Introducing Functional Grammar. London: Arnold.

Vanhove, Jan 2014. Receptive Multilingualism Across the Lifespan. Cognitive and Linguistic Factors in Cognate Guessing. Dissertation zur Erlangung der Doktorwürde. Universität Freiburg.

Zeevaert, Ludger, Jan D. ten Thije 2007. Introduction. - Jan D. ten Thije, Ludger Zeevaert (Eds.). Receptive Multilingualism. Linguistic Analyses, Language Policies and Dialectic Concepts. Amsterdam: John Benjamins, 1-21. 


\section{Liite 1. Sild üle mere (Terttu Nurro)}

Soome Instituut asutati Eestis aastal 1994 kahe maa vaheliste kultuuri- ja hariduskoostöö arendamiseks, informatsiooni levitamiseks Soome kohta ning Soome ja Eesti vaheliste sidemete tugevdamiseks kõigis ühiskondliku ja majanduselu valdkondades.

Soome ja Eesti pealinnu eraldab teineteisest vaid kitsas riba Soome lahte: vahemaad on vaevalt 80 kilomeetrit ja kolm tundi laevasõitu. Soome ja eesti keel on lähedased sugulaskeeled. Lisaks Soomele ja Eestile on maailmas vaid üks riik, mille riigikeel kuulub soomeugri keelerühma: Ungari. Selliste omavahel suguluses olevate väikeste keelte puhul, nagu seda on soome ja eesti keel, on lähedane kultuurialane partnerlus loomulikult oluline mõlema poole jaoks. Soome Instituudi direktor Juhani Salokannel kasutab sellele kultuurisuhtele viidates tihti väljendit 'kaarsild'. Muide, kaarsilda on kasutatud ka instituudi logol, kuigi logo pilt võiks sümboliseerida ka vikerkaart - mõlemal pool on rahapada.

Kultuurisidemed Soome ja Eesti vahel on kestnud juba pikka aega. Ajalugu on neid kahte suurte riikide naabrit karmilt kohelnud ja rahvuslik ärkamine, mis toimus mõlemal maal 19. ja 20. sajandi vahetusel, lähendas neid kahte maad. Isegi riikide rahvushümnide viis on ühine. Kuid Teine maailmasõda eraldas need kaks riiki teineteisest: Eestist sai üks Nõukogude liiduvabariikidest ja see raskendas vaba suhtlemist peaaegu viiekümneks aastaks. Nõukogude Liidu nõrgenemisele ja viimaks ka kokkuvarisemisele järgnes Eestis uus ärkamisaeg ja pärast seda iseseisvuse väljakuulutamine 1991. aastal. Soov vanad partnerlussuhted taastada oli suur Soome lahe mõlemal kaldal ja Tallinnas avatigi peagi väike Soome Kultuurikeskus. See toimis esialgu Soome Tuglase Seltsi, Eesti sõprade ühingu osakonnana, hiljem arenes see praeguseks Soome Instituudiks. Instituut asutati aastal 1993.

Kui Soome Instituut viimaks 1994. aasta alguses tööd alustas, oli tegu pigem omamoodi taasühinemise, mitte uute suhete loomisega. Juba olemasolev koostöö lihtsalt organiseeriti ümber ja sellele anti uus nimi. 


\title{
Co-text and intelligibility of Estonian language on the basis of a cognate language
}

\author{
PIRKKO MUIKKU-WERNER \\ University of Eastern Finland
}

When trying to understand their cognate language, people utilise the similarity of the forms and words of the language in question. However, superficial resemblance between word forms does not guarantee that the text will be understood; in fact, it might not even be necessary. Alongside the similarities between cognate languages, other variables such as the co-text have to be considered. Interpreting the meaning potential of linguistic expressions involves choosing from a set of options. Departing from this, we can study how the degree of freedom of situational choices constrains the translation process.

On the basis of previous research we know that Finnish speakers may fail to recognise even those Estonian words which have a conspicuously similar cognate in Finnish, if they are presented disconnected. However, if the words are situated in a coherent context, the wide range of possible translation equivalents is substantially reduced. In this article I try to answer the question how the close co-text influences the translation process. The analysed examples come from a translation test with Finnish students who had neither previous exposure to the Estonian language nor instruction in it.

The preliminary results show that when an Estonian word collocates with few words only and the alternatives are limited, a correct translation is possible. Since the limitations of options are not language-dependent but more or less universal, the correct meaning can be guessed even if the expressions in the two cognate languages are not visibly similar.

Unfortunately, the impact of the co-text is not always positive. Knowledge of case government in the mother tongue can lead to a wrong interpretation. Different case government in Estonian (for instance, Estonian lisaks 'in addition to' requires the allative case, while its Finnish equivalent lisäksi requires the genitive case) seems to present translation problems even if the words in the phrase are similar. 
Furthermore, the article addresses some possible further avenues of research. How is, for example, semantic priming used in receptive multilingualism when trying to find a meaning for a phraseological unit? For example the collocation of mother and father seems to be universal. It will be interesting to find out if semantic regularities could be utilised in order to facilitate the understanding of cognate languages.

Keywords: receptive multilingualism; similarity; phraseological unit; collocation; government; priming

\section{Pirkko Muikku-Werner}

Itä-Suomen yliopisto, humanistinen osasto, suomen kieli ja kulttuuritieteet

PL 111

80101 Joensuu, Finland

pirkko.muikku-werner@uef.fi 